\title{
Rhizobacterial isolates of Capsicum chinense inhibited fungal pathogen Rhizoctonia solani
}

\author{
Phazna Devi T.A. ${ }^{1}$, Dinabandhu Sahoo ${ }^{1}$, Indira Devi $\mathbf{S}^{{ }^{*}}$, Kalita M.C. ${ }^{2}$, Aravind Setti $^{3}$ \\ ${ }^{1}$ Institute of Bioresources and Sustainable Development (IBSD), Takyelpat, Imphal West, Manipur, India \\ ${ }^{2}$ Department of Biotechnology, Gauhati University, Guwahati, Assam, India \\ ${ }^{3}$ Department of Genetics, Osmania University, Hyderabad, Telangana State, India \\ *Corresponding Author: indiraibsd@gmail.com,Ph: 0385-2446122, Fax: 0385-2446121
}

Available online at: www.isroset.org

Received: 05/Feb/2019, Accepted: 13/Feb/2019, Online: 28/Feb/2019

\begin{abstract}
Umorok (Capsicum chinense) is a commercially important chilli plant of Northeastern India. To improve the overall growth and health of the plant we explore the rhizosphere bacteria associated with the plant through serial dilution and pure culture method from three different growth stages juvenile, flowering and fruiting stage. The isolated rhizobacteria were then screened for their biocontrol enzyme activities like cellulose, protease and chitinase, and the potential isolates were molecular characterized using $16 \mathrm{~S}$ rRNA gene sequencing. The identified microorganism were then studied for its antagonism assay against the fungal pathogen Rhizoctonia solani using dual culture method. The isolates which showed the highest antagonism were selected and treated with the pathogen infected Umorok plant and measured the growth indicating traits in the greenhouse experiment. During the molecular characterization of the rhizobacteria, 127 novel strains were identified. Five bacterial phyla were observed in the three growth stages, and gammaproteobacteria were predominantly present among them. Seven potential rhizobacteria were selected from the diverse list of rhizobacteria showing the biocontrol and antagonism assays. Umorok was infected with plant pathogen $R$. solani and treated with the selected rhizobacteria to measure the plant growth. The findings confirmed that Lysobacter enzymogenesis competitively inhibited the $R$. solani and significantly improved the shoot and root system.
\end{abstract}

Keywords: Rhizobacteria, Umorok, Antagonism, Molecular characterization, Rhizoctonia solani

\section{INTRODUCTION}

Biotic and abiotic factors influence the plant growth in juvenile, flowering, and fruiting stages of the plant and eventually affect the productivity [1]. Clear knowledge on plant and biotic factors - plant growth promoting rhizobacteria (PGPR) and pathogenic microbiota - facilitate the effective cultivation strategies to circumvent the biotic stress [2]. The plant developmental stage specifically recruits the wide range of rhizobacteria during typical growth cycle; often competitive symbiotic association represses the diseases causing plant pathogens $[3,4]$. Fungi is the common threat to the crop loss and fungal pathogen elimination is a challenging process [5]. In some cases, coculture studies of fungal pathogens and rhizobacteria on microbial culturedish demonstrated the inhibition of the fungal pathogens [6]. Plant growth promoting bacterial associations have been demonstrated the improved productivity in several commercial and vegetable crops.
Capsicum chinense is an indigenous Northeast Indian chilli variety and known for its high capsaicin content. Poor agronomical practices and lack of scientific information on pathogenic attacks and soil bacteria are the key reasons for less yield. Recent studies revealed the influence of water stress on production and pungency [7], fresh pepper chemical profile contained relatively high amount of capsaicinoids and antioxidants [8], and the air dried extracts were able to inhibit the food born pathogens Staphylococcus aureus and Listeria monocytogenes $[9,10]$. C. chinense contains a variety of capsaicinoids and were separated using reverse phase liquid chromatography [11]. If the chemical profile of the capsaicin is unveiled, it can be used to treat the wide range of pathological conditions. Effect of capsaicin was studied on pain, inflammation, cell proliferation, and apoptosis [12]. The protective role of capsaicin in autoimmune diseases also described elsewhere [13], and health benefits of capsaicin was demonstrated in preclinical and clinical research [14]. After realizing the importance of capsaicin in various applications, it is essential to develop a 
pungent capsaicin for spectrum of medical applications. In fact, $C$. chinense has been considered as the world's hottest chili; therefore, studying plant pathogen effects and rhizobacterial growth promoting effects play a central role in the yield potential.

Although India is the major producer of the chili, plant pathogens and abiotic factors impede the annual production. It was observed that Phytophthora capsici causes damping off [15], and Colletotrichum produces anthracnose disease. An PCR based molecular markers were developed to distinguish the variety of Colletotrichum fungal pathogens [16]. It was established that rhizobacteria not only promote the plant growth, merely providing chemical nutrients, but also inhibit the pathogenic fungi or bacteria [17,18]. A study described the rhizobacterial isolate, Pseudomonas fluorescens, of Capsicum annum controlled the wilt disease caused by Fusarium solani [19]. Fungal root pathogen Rhizoctonia solani causes root rot in several plants including chili and antagonistic potential of rhizobacteria against $R$. solani was demonstrated in maize, tomato, and potato $[1,20,21]$; however, it is yet to be studied in chilli.

Rhizobacterial profile of $C$. chinense was least studied, and we attempted to study the comprehensive rhizobacteria of $C$. chinense. Further, the antagonistic effect of rhizobacterial isolates against Rhizoctonia solani was studied because it is the potential threat in the chilli crop loss in Northeast India.

Rest of the paper is organized as follows, Section I contains the introduction of biotic stress of plant, Section II contain the introduction of Capsisicum chinense, Section III contain the diseases associated with chilli plant, Section IV contain the architecture and hypothesis of the study, section V explain the material and methods, Section VI describes results, Section VII contain discussion and Section VIII concludes research work with future directions.

\section{MATERIAL \& METHODS}

\section{Rhizobacteria isolation}

Capsicum chinense seeds were collected from the Imphal, Manipur, India. Seeds were surface sterilized with $70 \%$ ethanol and $4 \%$ hypochlorite and allowed to sprout on $1 \%$ agar before transferring onto the pots containing unsterile soil. After reaching the plant a distinct growth stage; juvenile, flowering, and fruiting; the soil around the plant root was collected. Roots were placed in sterile distilled water and briefly vortexed and sonicated to remove the soil aggregates and microbes. The turbid form of the water was centrifuged for $5 \mathrm{~min}$ at $8000 \mathrm{~g}$ to collect the rhizobacteria. 1 $\mathrm{g}$ soil fraction was serially diluted and plated onto the Luria Bertani Agar, King's B Medium, Pikovskaya's Agar, Tryptic Soy Agar, Brain Heart Infusion Agar, and Rojo Congo Medium plates using standard spread plate method. The rhizobacteria inoculated bacterial plates were incubated at $30{ }^{\circ} \mathrm{C}$ for 2-3 days until growth appeared on the plates.
Morphologically distinct colonies were sub cultured for several rounds to isolate the pure colonies.

\section{Molecular characterization}

The pure cultures of the rhizobacteria were characterized based on 16S rDNA for molecular identification. The bacterial DNA was isolated using standard lysozyme method. For bacterial species and strain identification $16 \mathrm{~S}$ rDNA was amplified in PCR using $63 \mathrm{~F}$ and $1387 \mathrm{R}$ primers. The PCR product amplified from each pure culture was subjected to Sanger DNA sequencing. The sequencing result was compared with National Center for Biotechnology Information (NCBI) nucleotide database using Basic Local Alignment Search Tool (BLAST).

\section{Identification of potential rhizobacteria}

Cellulase, protease, and chitinase activities of bacterial pure culture were assayed following standard protocols. Reported method of carboxymethyl cellulose containing media was prepared for the cellulase activity testing [22]. Skim milk agar media and colloidal chitin agar media were used to test the protease and chitinase activity of the rhizobacteria $[23,24]$. The zone of inhibition around the inoculated colony was measured for the quantification.

\section{Antagonism assay}

The potential rhizobacteria that were identified in biocontrol assays were used for the antagonism studies. The plant fungal pathogen Rhizoctonia solini was obtained from Indian Type Culture Collection (ITCC), New Delhi, India to coculture with the rhizobacteria. Both $R$. solani and single rhizobacterial strain were inoculated onto the potato dextrose agar (PDA) plate; after 3 day incubation, inhibition zone of $R$. solani was measured.

\section{Green house experiment}

Pathogenic fungi $R$. solani was propagated on $100 \mathrm{~g}$ of wheat grains for ten days and inoculated into the sterile soil containing pots. The separately grown juvenile chilli plant in the green house was treated with single rhizobacterial strain. The treated chili plant was transferred into the fungi contaminated soil pot until fruiting stage. Shoot length, root length, shoot dry weight, root dry weight, and number of fruits per plant were measured.

\section{RESULTS}

About 300 rhizobacterial pure culture strains were isolated from the Capsicum chinense and characterized based on $16 \mathrm{~S}$ rDNA sequencing. Ribosomal 16S rDNA sequences of rhizobacterial isolates were compared with existing bacterial strains in the NCBI nucleotide database. All the novel bacterial strains were submitted to NCBI nucleotide database, accession numbers KY038202 - KY038328. We found varied diversity of alphaproteobacteria, betaproteobacteria, gammaproteobacteria, actinobacteria, 
and firmicutes in juvenile, flowering, and fruiting stages (Figure 1). Of all the rhizobacteria, gammaproteobacteria dominantly present across the life stages of $C$. chinense, while firmicutes were seen less. On the other hand, betaproteobacteria exclusively present in flowering and fruiting stages.

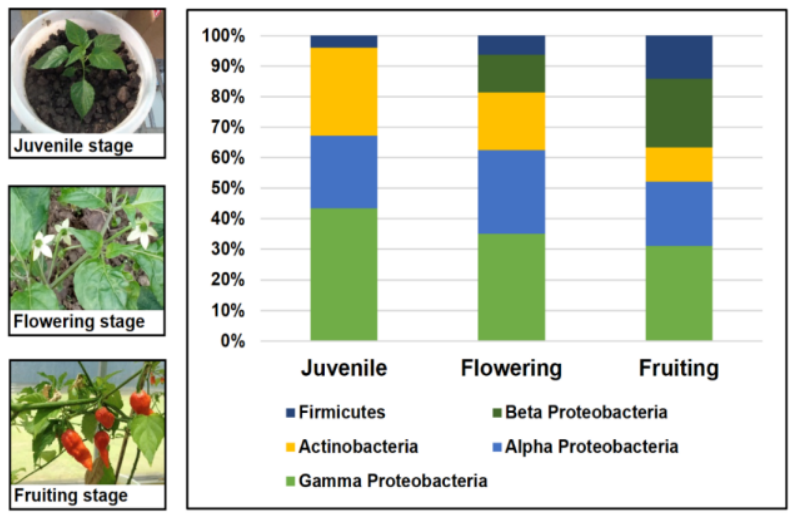

Figure 1: Rhizobacterial diversity of Capsicum chinense in juvenile, flowering, and fruiting stages. Gammaproteobacteria were largely found in all the plant growth stages followed by alphaproteobacteria, actinobacteria, betaproteobacteria, and firmicutes. Betaproteobacteria were absent in juvenile stage.

Biocontrol tests identified the potential plant growth promoting rhizobacteria. Biocontrol activity of the rhizobacteria was assessed for cellulase, protease, and chitinase activity (Figure 2, A-C). The zone of inhibition of all the rhizobacterial isolates was measured, and the lead bacteria were co-cultured with fruit rot causing fungal chilli pathogen $R$. solani in the antagonism assay to show the percentage of pathogen inhibition (Table 1). Rhizobacterial isolates of $C$. chinense inhibited the plant pathogen $R$. solani (Figure 2, D and E), and Lysobacter enzymogenesis (PF100) potentially inhibited $33 \%$ of the pathogen.


Figure 2: Biocontrol and antagonism properties of plant growth promoting rhizobacteria. Biocontrol properties of rhizobacteria: A) cellulase activity, B) protease activity, and C) chitinase activity. Antagonism property of rhizobacteria: D) fully grown control plate of Rhizoctonia solani and E) Dual culture plate of Rhizoctonia solani and rhizobacterial strains F) T, pathogen and rhizobacteria treated plant; C, rhizobacteria and pathogen untreated control; $\mathrm{P}$, pathogen treated plant.

Table 1: Biocontrol activities of the potential rhizobacterial isolates and Rhizoctonia solani inhibition percentage of $C$. chinense in the culture plates are showing the values with standard deviation.

\begin{tabular}{lllllll}
\hline $\begin{array}{l}\text { S. } \\
\text { No. }\end{array}$ & Name of the Rhizobacteria & $\begin{array}{l}\text { NCBI } \\
\text { Accession } \\
\text { no. }\end{array}$ & $\begin{array}{l}\text { Cellulase } \\
\text { activity } \\
\text { (in cm) }\end{array}$ & $\begin{array}{l}\text { Protease } \\
\text { activity } \\
\text { (in cm) }\end{array}$ & $\begin{array}{l}\text { Chitinase } \\
\text { activity } \\
\text { (in cm) }\end{array}$ & $\begin{array}{l}\text { Rhizoctonia } \\
\text { solani } \\
\text { inhibition (\%) }\end{array}$ \\
\hline 1 & $\begin{array}{l}\text { Lysobacter enzymogenesis } \\
\text { (PF100) }\end{array}$ & KY038296 & $1.02 \pm 0.02$ & $1.4 \pm 0.01$ & $0.99 \pm 0.01$ & $33.06 \pm 0.25$ \\
2 & Lysobacter enzymogenesis (PF47) & KY038215 & $1.11 \pm 0.01$ & $1.7 \pm 0.01$ & $1.5 \pm 0.01$ & $26.4 \pm 0.26$ \\
3 & Pseudomonas sp (PT5) & KY038276 & $0.49 \pm 0.01$ & $1.81 \pm 0.01$ & $0.31 \pm 0.01$ & $17.53 \pm 0.15$ \\
4 & Bacillus altitudinis (PS9) & KY038229 & $0.7 \pm 0.01$ & $0.9 \pm 0.01$ & $0.21 \pm 0.01$ & $26.3 \pm 0.26$ \\
5 & Pseudomonas sp (PB6) & KY038267 & $0.41 \pm 0.02$ & $1.9 \pm 0.01$ & $1.09 \pm 0.01$ & $17.5 \pm 0.2$ \\
6 & Bacillus altitudinis (PT48) & KY038301 & $0.61 \pm 0.02$ & $0.81 \pm 0.01$ & $0.3 \pm 0.01$ & $13.2 \pm 0.1$ \\
7 & Lysinibacillus xylanilyticus (PT26) & KY038297 & $0.4 \pm 0.02$ & $0.3 \pm 0.01$ & $0.11 \pm 0.01$ & $8.7 \pm 0.1$ \\
\hline
\end{tabular}

and chitinase activity. When fungi infected Umorok were treated with rhizobacteria, plant length, foliage, and health were improved (Figure 2, F). Disease control, shoot length, root length, shoot dry weight, root dry weight, and number of fruits per plant were significantly $(\mathrm{p}<0.0001)$ improved in pathogen and rhizobacteria treated plants when compared to untreated control and pathogen alone treated plants (Table 2). 
Table 2: Disease incidence and plant growth parameter measurements with standard deviation of pathogen $R$. solani infected and rhizobacteria treated Umorok in greenhouse experiment.

\begin{tabular}{|c|c|c|c|c|c|c|c|}
\hline $\begin{array}{l}\text { S. } \\
\text { No. }\end{array}$ & Name of Organism & $\begin{array}{l}\text { Disease } \\
\text { incidence } \\
\%\end{array}$ & $\begin{array}{l}\text { Shoot } \\
\text { Length } \\
\text { (cm) }\end{array}$ & $\begin{array}{l}\text { Root length } \\
\text { (cm) }\end{array}$ & $\begin{array}{l}\text { Dry weight } \\
\text { of shoot }(\mathrm{g})\end{array}$ & $\begin{array}{l}\text { Dry weight } \\
\text { of root }(\mathrm{g})\end{array}$ & $\begin{array}{l}\text { No. } \\
\text { fruits }\end{array}$ \\
\hline 1 & $\begin{array}{l}\text { Lysobacter } \\
\text { enzymogenes (PF100) }\end{array}$ & $15.6 \pm 1.52$ & $55.73 \pm 0.15$ & $14.56 \pm 0.15$ & $125.4 \pm 0.26$ & $4.86 \pm 0.06$ & $53 \pm 1$ \\
\hline 2 & $\begin{array}{l}\text { Lysobacter } \\
\text { enzymogenes (PF47) }\end{array}$ & $16.3 \pm 1.52$ & $52.7 \pm 0.2$ & $13.63 \pm 0.3$ & $120.54 \pm 0.17$ & $4.86 \pm 0.1$ & $52 \pm 1$ \\
\hline 3 & $\begin{array}{l}\text { Pseudomonas } \\
\text { (PT5) }\end{array}$ & $18.3 \pm 1.52$ & $50.26 \pm 0.45$ & $11.76 \pm 0.25$ & $105.18 \pm 0.2$ & $4.36 \pm 0.29$ & $49 \pm 1$ \\
\hline 4 & $\begin{array}{l}\text { Bacillus altitudinis } \\
\text { (PS9) }\end{array}$ & $20 \pm 1$ & $48.86 \pm 0.25$ & $11.56 \pm 0.3$ & $104.56 \pm 0.37$ & $4.48 \pm 0.25$ & $48 \pm 1$ \\
\hline 5 & $\begin{array}{l}\text { Pseudomonas } \\
\text { (PB6) }\end{array}$ & $23.3 \pm 1.52$ & $48.53 \pm 0.2$ & $10.7 \pm 0.26$ & $102.56 \pm 0.29$ & $4.06 \pm 0.04$ & $49 \pm 1$ \\
\hline 6 & $\begin{array}{l}\text { Bacillus altitudinis } \\
\text { (PT48) }\end{array}$ & $25 \pm 1$ & $48.43 \pm 0.2$ & $12.56 \pm 0.3$ & $80.46 \pm 0.25$ & $3.94 \pm 0.06$ & $44.6 \pm 1.5$ \\
\hline 7 & $\begin{array}{l}\text { Lysinibacillus } \\
\text { xylanilyticus (PT26) }\end{array}$ & $26.3 \pm 1.52$ & $46.53 \pm 0.25$ & $9.4 \pm 0.2$ & $82.52 \pm 0.3$ & $3.86 \pm 0.04$ & $41.3 \pm 1.5$ \\
\hline 8 & Control & $29 \pm 1$ & $45.46 \pm 0.2$ & $8.6 \pm 0.3$ & $70.5 \pm 0.25$ & $3.53 \pm 0.05$ & $36.66 \pm 1.5$ \\
\hline
\end{tabular}

\section{DISCUSSION}

Rhizobacteria form symbiotic association with the plants and play a critical role in the plant growth and health. Rhizobacterial isolates demonstrated the antifungal activity in other plants [25-27], whereas chitinolytic bacteria isolated from chilli rhizosphere controlled the whitefly [28], but the role of chilli rhizobacterial isolates on plant growth and fungal pathogen inhibition was unestablished. We isolated pure cultures of Umorok rhizobacteria from juvenile, flowering, and fruiting stages to validate their impact on plant growth and health. Rhizobacteria were molecular characterized using 16S rRNA gene sequencing, and novel species were submitted to NCBI - Nucleotide database. Rhizobacterial diversity unveiled the abundant gammaproteobacteria in three stages, and the similar phyla were observed in the other plants [29]. Betaproteobacteria was absent in juvenile stage but appeared in the subsequent stages (Figure 1). This result confers the stage specific diversity of rhizobacteria in the Umorok rhizosphere, which is common in other plants as well [30].

Biocontrol and antagonism tests identify the potential plant growth promoting bacteria [31]. Fungi cause a wide range of diseases in plants, and $R$. solani causes fruit rot in Umorok plant. Fungal cell wall contains cellulose, proteins, and chitin, so cellulase, protease, and chitinase activities are desirable from the rhizobacterial community. We identified seven potential rhizobacteria, evaluated antagonism activity on $R$. solani in culture plates, and treated with rhizobacteria with pathogen infected Umorok plant (Figure 2). Lysobacter enzymogenesis (PF100) accelerated the pathogen treated plant growth significantly. A study proved that Lysobacter sps. appear in the disease suppressive soils [32], and it supported our results.
Shoot and root system determines the plant growth and health; hence, pathogen infected Umorok plant was treated with variety of rhizobacteria. Shoot length, root length, shoot dry weight, root dry weight, and disease incidence were measured and means were statistically compared with the control groups. Statistically significant results of greenhouse experiments conferred that Lysobacter enzymogenesis competitively inhibited pathogenic fungi Rhizoctonia solani in the Umorok plant. The findings provided the insights into the rhizobacterial diversity of Umorok plant and their impact on the plant growth and pathogen inhibition. Since the identified bacteria elicited potential biocontrol and antagonism activity against $R$. solani, these rhizobacteria can be recommended and tested in $R$. solani associated diseases in other crops.

\section{CONCLUSION}

Umorok is an important commercial crop which is famous for its high capsaicin and pungency. We anticipated rhizosphere plays a central role in the plant growth and health, therefore we isolated rhizobacteria of Umorok and submitted 127 novel bacterial strains to NCBI - Nucleotide database. Diverse rhizobacteria were associated with the juvenile, flowering, and fruiting stages of Umorok, and gammaproteobacteria were predominantly present in all the three stages. Biocontrol tests identified the potential cellulose, protein, and chitin degrading bacteria which on antagonism assay inhibited the fungal pathogen Rhizoctonia solani. From the greenhouse experiment, we proved Lysobacter enzymogenesis competitively inhibited the fungal pathogen significantly and improved the shoot length, root length, shoot dry weight, and root dry weight. Although individual bacteria were tested for their pathogen inhibiting activity, the synergetic effect of rhizobacteria is further needed to be studied. This study identified $R$. solani 
inhibiting potential rhizobacteria, which likely to be used in other plants as well.

\section{Acknowledgement}

We thank MRD, IBSD and DBT, Govt of India for funding the project.

\section{Funding Information}

Authors thank the funding agency Department of Biotechnology (DBT), Ministry of Science \& Technology, Govt of India for the financial support.

\section{Author Contributions}

PD: Carried out the research work, DS: Guided and assisted in manuscript editing. AS: Statistical analysis and manuscript editing. MCK: Technical guidance in experimental issues. SI: Mentor of the project.

\section{REFERENCES}

[1]. Abdeljalil N, Renault D, Gerbore J, Vallance J, Rey P, Daamiremadi M. Comparative Efficacy of Three Tomato-Associated Rhizobacteria used Singly or in Combination in Suppressing Rhizoctonia Root Rot and Enhancing Tomato Growth. Microb Biochem Technol. OMICS International; 2016;8: 110-119. doi:10.4172/1948-5948.1000272

[2]. Vacheron J, Desbrosses G, Bouffaud M-L, Touraine B, MoënneLoccoz Y, Muller D, et al. Plant growth-promoting rhizobacteria and root system functioning. Front Plant Sci. Frontiers Media SA; 2013;4: 356. doi:10.3389/fpls.2013.00356

[3]. Syed Ab Rahman SF, Singh E, Pieterse CMJ, Schenk PM. Emerging microbial biocontrol strategies for plant pathogens. Plant Science. Elsevier; 2018. pp. 102-111. doi:10.1016/j.plantsci.2017.11.012

[4]. Lugtenberg B, Rozen DE, Kamilova F. Wars between microbes on roots and fruits. F1000Research. Faculty of $1000 \mathrm{Ltd}$; 2017;6: 343. doi:10.12688/f1000research.10696.1

[5]. Franceschetti M, Maqbool A, Jiménez-Dalmaroni MJ, Pennington HG, Kamoun S, Banfield MJ. Effectors of Filamentous Plant Pathogens: Commonalities amid Diversity. Microbiol Mol Biol Rev. American Society for Microbiology; 2017;81: e00066-16. doi:10.1128/MMBR.00066-16

[6]. Compant S, Duffy B, Nowak J, Clément C, Barka EA. Use of plant growth-promoting bacteria for biocontrol of plant diseases: Principles, mechanisms of action, and future prospects. Applied and Environmental Microbiology. American Society for Microbiology (ASM); $2005 . \quad$ pp. 4951-4959. doi:10.1128/AEM.71.9.4951-4959.2005

[7]. Jeeatid N, Techawongstien S, Suriharn B, Chanthai S, Bosland $\mathrm{PW}$, Techawongstien S. Influence of water stresses on capsaicinoid production in hot pepper (Capsicum chinense Jacq.) cultivars with different pungency levels. Food Chem. Elsevier; 2018;245: 792-797. doi:10.1016/j.foodchem.2017.11.110

[8]. Loizzo MR, Pugliese A, Bonesi M, Menichini F, Tundis R. Evaluation of chemical profile and antioxidant activity of twenty cultivars from Capsicum annuum, Capsicum baccatum, Capsicum chacoense and Capsicum chinense: A comparison between fresh and processed peppers. LWT - Food Sci Technol. Academic Press; 2015;64: 623-631. doi:10.1016/J.LWT.2015.06.042

[9]. Loizzo MR, Bonesi M, Serio A, Chaves-López C, Falco T,
Paparella A, et al. Application of nine air-dried Capsicum annum cultivars as food preservative: Micronutrient content, antioxidant activity, and foodborne pathogens inhibitory effects. Int J Food Prop. Taylor \& Francis; 2017;20: 899-910. doi:10.1080/10942912.2016.1188310

[10]. Vargas-Hernández M, Torres-Pacheco I, Gautier F, ÁlvarezMayorga B, Cruz-Hernández A, García-Mier L, et al. Influence of hydrogen peroxide foliar applications on in vitro antimicrobial activity in Capsicum chinense Jacq. Plant Biosyst An Int J Deal with all Asp Plant Biol. Taylor \& Francis; 2017;151: 269-275. doi:10.1080/11263504.2016.1168494

[11]. Stipcovich T, Barbero GF, Ferreiro-González M, Palma M, Barroso CG. Fast analysis of capsaicinoids in Naga Jolokia extracts (Capsicum chinense) by high-performance liquid chromatography using fused core columns. Food Chem. Elsevier; 2018;239: 217-224 doi:10.1016/J.FOODCHEM.2017.06.098

[12]. Güler S, Zik B. Effects of capsaicin on ovarian granulosa cell proliferation and apoptosis. Cell Tissue Res. Springer Berlin Heidelberg; 2018; 1-7. doi:10.1007/s00441-018-2803-4

[13]. Deng Y, Huang X, Wu H, Zhao M, Lu Q, Israeli E, et al. Some like it hot: The emerging role of spicy food (capsaicin) in autoimmune diseases. Autoimmunity Reviews. Elsevier; 2016. pp. 451-456. doi:10.1016/j.autrev.2016.01.009

[14]. McCarty MF, DiNicolantonio JJ, O'Keefe JH. Capsaicin may have important potential for promoting vascular and metabolic health. Open Hear. BMJ Publishing Group; 2015;2: e000262. doi:10.1136/openhrt-2015-000262

[15]. Sánchez-Borges CA, Souza-Perera RA, Zúñiga-Aguilar JJ, Shrestha S, Lamour K, Castillo-Aguilar CC. First Report of Phytophthora capsici Causing Damping-off of Capsicum chinense in the Yucatan Peninsula. Plant Dis. Plant Disease; 2015;100: 1247. doi:10.1094/PDIS-09-15-1047-PDN

[16]. de Oliveira CVS, Matos KS, De Albuquerque DMC, Hanada RE, Da Silva GF. Identification of Colletotrichum isolates from Capsicum chinense in Amazon. Genet Mol Res. Genetics and Molecular Research; 2017;16. doi:10.4238/gmr16029601

[17]. Beneduzi A, Ambrosini A, Passaglia LMP. Plant growthpromoting rhizobacteria (PGPR): Their potential as antagonists and biocontrol agents. Genetics and Molecular Biology. Sociedade Brasileira de Genética; 2012. pp. 1044-1051. doi:10.1590/S1415-47572012000600020

[18]. Olanrewaju OS, Glick BR, Babalola OO. Mechanisms of action of plant growth promoting bacteria. World J Microbiol Biotechnol. Springer; 2017;33: 197. doi:10.1007/s11274-0172364-9

[19]. Sundaramoorthy S, Raguchander T, Ragupathi N, Samiyappan R. Combinatorial effect of endophytic and plant growth promoting rhizobacteria against wilt disease of Capsicum annum L. caused by Fusarium solani. Biol Control. Academic Press; 2012;60: 59-67. doi:10.1016/J.BIOCONTROL.2011.10.002

[20]. Priya S, Upadhyay JP. Antagonistic Potential of Trichoderma harzianum against Rhizoctonia solani Causing Banded Leaf and Sheath Blight of Maize. IntJCurrMicrobiolAppSci. 2017;6: 886890. doi:10.20546/ijcmas.2017.610.106

[21]. Selva Kumar S, Ram Krishna Rao M, Deepak Kumar R, Panwar S, Prasad CS. Biocontrol by plant growth promoting rhizobacteria against black scurf and stem canker disease of potato caused by Rhizoctonia solani. Arch Phytopathol Plant Prot. Taylor \& Francis; 2013;46: 487-502. doi:10.1080/03235408.2012.745054

[22]. Aneja KR. Experiment in Microbiology, Plant Pathology and Biotechnology, 4th Edn. New Age International Publishers; 2003.

[23]. Agrawal, T., and Kotasthane AS. A simple medium for screening chitinase activity of Trichoderma spp. In: Methods of 
Molecular Identification and laboratory Protocols (International Subcommission on Trichoderma and Hypocrea Taxonomy (ISTH)) [Internet]. 2009. Available: http://www.isth.info/methods/method.php?method_id=11.

[24]. Kazanas N. Proteolytic Activity of Microorganisms Isolated from Freshwater Fish. Appl Microbiol. 1968;16: 128-132.

[25]. Bjelić D, Marinković J, Tintor B, Mrkovački N. Antifungal and Plant Growth Promoting Activities of Indigenous Rhizobacteria Isolated from Maize (Zea mays L.) Rhizosphere. Commun Soil Sci Plant Anal. Taylor \& Francis; 2018;49: 88-98. doi:10.1080/00103624.2017.1421650

[26]. Avinash TS, Rai R V. Antifungal Activity of Plant Growth Promoting Rhizobacteria Against Fusarium oxysporum and Phoma sp. of Cucurbitaceae. Microbial Diversity and Biotechnology in Food Security. New Delhi: Springer India; 2014. pp. 257-264. doi:10.1007/978-81-322-1801-2_23

[27]. Sarbadhikary SB, Mandal NC. Field application of two plant growth promoting rhizobacteria with potent antifungal properties. Rhizosphere. Elsevier; 2017;3: 170-175. doi:10.1016/j.rhisph.2017.04.014

[28]. Mubarik NR, Mahagiani I, Anindyaputri A, Santoso S, Rusmana I. Chitinolytic bacteria isolated from chili rhizosphere: Chitinase characterization and its application as biocontrol for whitefly (Bemisia tabaci genn.). Am J Agric Biol Sci. 2010;5: 430-435. doi:10.3844/ajabssp.2010.430.435

[29]. Köberl M, Dita M, Martinuz A, Staver C, Berg G. Members of Gammaproteobacteria as indicator species of healthy banana plants on Fusarium wilt-infested fields in Central America. Sci Rep. Nature Publishing Group; 2017;7: 45318. doi: $10.1038 /$ srep45318

[30]. Inceoğlu Ö, Al-Soud WA, Salles JF, Semenov A V., van Elsas JD. Comparative analysis of bacterial communities in a potato field as determined by pyrosequencing. Gilbert JA, editor. PLoS One. Public Library of Science; 2011;6: e23321. doi:10.1371/journal.pone.0023321

[31]. Dinesh R, Anandaraj M, Kumar A, Bini YK, Subila KP, Aravind R. Isolation, characterization, and evaluation of multitrait plant growth promoting rhizobacteria for their growth promoting and disease suppressing effects on ginger. Microbiol Res. Urban \& Fischer; 2015;173: 34-43. doi:10.1016/j.micres.2015.01.014

[32]. Gómez Expósito R, Postma J, Raaijmakers JM, De Bruijn I. Diversity and Activity of Lysobacter Species from Disease Suppressive Soils. Front Microbiol. Frontiers Media SA; 2015;6: 1243. doi:10.3389/fmicb.2015.01243 